10.00 (average of eleven specimens, 9.19); tail, 6.20-7.10 (average, 6.62); culmen, .70-.82 (average, .75); tarsus, 2.35-2.65 (average, 2.54); middle toe, 1.15-1.30 (average, 1.24).

The specimens of this new form (including eight examples in alcohol) were collected by the naturalists of the United States Fish Commission steamer Albatross, Capt. Z. L. Tanner, commander.

\title{
ON A NEW SPECIES OF PORPOISE, PHOCAENA DALLI, FROM AL ASKA.
}

BY FREDERICK W. TRUE,

Curator of the Department of Mammals.

The species of Phoccena hitherto described are seven in number. These are-

Phoccena communis, Lesson.

Phoccna spinipinnis, Burmeister.

Phocana vomerina, Gill.

Phocena brachycion, Cope.

Phocana tuberculifera, Gray.

Phoccena lineata, Cope.

Phocana pectoralis, Peale.

The $P$. pectoralis of Peale, as I shall endeavor to prove in another communication, is in reality a Lagenorhynchus, and probably synonymous with $L$. electra, Gray. P. tuberculifera of Gray was finally admitted by that author to be only a variation of $P$. communis. The opinion has lately been expressed by Professor Flower that the last named species is probably cosmopolitan, and that $P$.brachycion and $P$.vomerina are synonymous with it.* If this view is correct, and I am inclined to believe that it may be, the known species of Phoccna will be reduced to three, namely, P. communis, lineata, and spinipinnis. To this list I am enabled to add a new species, through the kindness of Mr. William H. Dall, who has placed at my disposal his notes upon and drawings of two specimens of a peculiar porpoise belonging to the genus, captured off the coast of Alaska in 1873. The skeleton of one of these specimens was sent to the Army Medical museum in this city, where it was unfortunately destroyed by rats. The skull, however, was preserved and is now in the possession of the National Museum. The second specimen, which $I$ shall now describe, was one of a school of five or six met with in the strait west of Adakh Island, one of the Aleutian group, August 13, 1873. It proved to be a male.

\section{Phocena Dalli, sp. nov, (Plates II-V.)}

Length 6 feet. General color black. A cordate area of white occupies the belly and lower half of the sides, from a point in line with anterior margin of the dorsal fin to one considerably behind the vent. This area is faintly streaked with very fine dark lines, especially nu- 
merous near the median line, but only visible on close inspection. The dorsal fin is tipped with white. Eye blackish.

Head sloping. Lower jaw protruding slightly beyond the upper. Dorsal fin moderately high and falcate, its front edge furnished with five faintly-marked rugosities. Pectorals as in $P$. communis. Dorsal and ventral margins of the body, between the vent and the origin of the flukes, raised into a prominent thin ridge.

Skull as in $P$. communis, but the beak relatively shorter, and the temporal fossæ smaller. The maxillaries are also shorter proximally, and the mandible less deep between the coronoid process and angle. Numerous other differences of proportion will be found upon examination of the table on p. 98. The symphysis mandibuli is prolonged anteriorly into an obtuse point. Teeth $\frac{2}{2} \frac{3}{7}$, very small. The crown measures .065 by .05 inches, and is compressed as in other Phocænas, though in a less degree; the margin is not indented.

Vertebral formula as follows: C. 7 ; D. 14 (or $\left.15^{*}\right)$; L. 27 ; Ca. $49=97$ (or 98). All the cervicals united, as are also the last four caudals. First thirty caudals with chevron bones.

The pectoral corresponds closely to that of P. communis. Five carpals are present. The formula of phalanges is as follows: I, 1 ; II, 6 ; III, 4 ; IV, 2. The two distal phalanges of fingers 2 and 3 and the outermost of finger 4 are very imperfectly ossified.

I deem it eminently fitting that this species should be dedicated to my friend, Mr. William H. Dall, not alone on account of his prominence as a zoologist, but also because the specimens and notes from which the description has been drawn are the fruits of his labor.

\section{COMPARISON OF PHOCANA DALLI WITH OTHER SPECIES.}

The three main features in which $P$. Dalli differs from the remaining species of the genus are $(a)$ the coloration; $(b)$ the shape of the dorsal fin; and $(c)$ the number of vertebræ. In all these characters it shows an approximation to the species of Lagenorhynchus.

In P. spinipinnis we have, according to Burmeister, a species which is entirely black. $P$. communis and P. lineata, on the contrary, are dark or black upon the upper or dorsal surface of the body, and white or light upon the lower or ventral surface, the two opposite colors grading into each other on the sides. The coloration of $P$. Dalli differs from both these siyles in that the white or light area is confined to the posterior half of the ventral surface, and is sharply defined from the surrounding black color.

In his recent admirable paper upon the Delphinidae (Proc. Zool. Soc., 1883, p. 505), Professor Flower recognizes the triangular shape of the dorsal fin as among the salient characters of the genus Phoccena. Its shape is such in the species hitherto described, but in P. Dalli the tip is recurved, and the posterior margin concave, giving the fin approximately 


\section{Vol. VIII, No. 7. Washington, D. C. May 28, 1885.}

the falcate form existing in Delphinus. The rugosities on the upper margin appear to be similar to those which exist in other species of Phoccena, and which are most strongly developed in P. spinipinnis.

In the great number of its vertebræ, as already remarked, P. Dalli shows on important similarity to the Lagenorhynchi. The vertebral formulæ of the different species of Phocana and of one of Lagenorhynchus are as follows :

\begin{tabular}{|c|c|c|c|c|}
\hline Species. & C. & D. & L. Ca. & Total. \\
\hline Phocana communis....... & 7 & 13 & $14 \quad 32$ & $=66^{*}$ \\
\hline 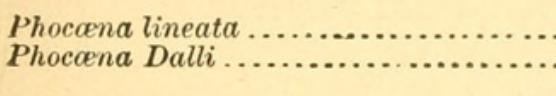 & $\begin{array}{l}7 \\
7\end{array}$ & $\begin{array}{l}11(\text { or } 12) \\
14(\text { or } 15)\end{array}$ & $\underbrace{27 \quad 49}$ & $\begin{array}{l}=63(\text { or } 64) \\
=97(\text { or } 98)\end{array}$ \\
\hline Lagenorhynchus albirostris... & 7 & 14 & 67 & $=88^{*}$ \\
\hline
\end{tabular}

* Flower, Cat. Osteol., College of Surgeons, pt. ii. 1884, pp. 570 and 582.

In view of the existence of these three characters in a species otherwise evidently allied to $P$. communis, it would appear to be necessary to modify the diagnosis of the genus, and to base the latter simply upon the peculiar shape of the teeth and the form and position of the pterygoids.

Mr. Dall states in his notes that the species under consideration is recognized by the Aleuts as distinct from the smaller bay porpoise or puffing pig, P. vomerina, Gill (?=P. communis), which is also found about the Aleutian Islands. The latter species is called al-âa-túkh, while P. Dalli known as $k \bar{u} d \cdot \bar{a} h^{\prime} \cdot t i k h$, the word $a h-t u ̌ k h$, as Mr. Dall further explains, signifying whales in general.

Measurements of the exterior of a specimen of Phoccena Dalli captured off Adakh Island, August 13, 1873.

[These measurements are in straight lines, the curves of the body being excluded.]

Inches.

Total length

72.0

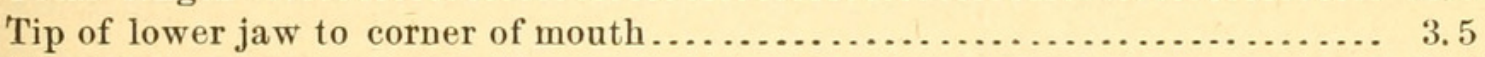

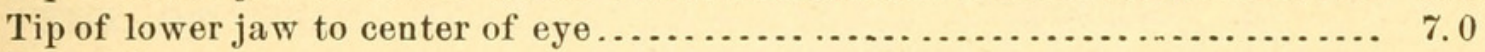

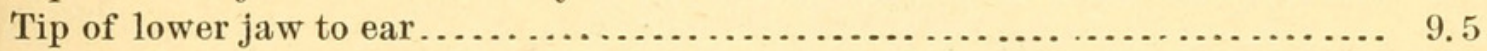

Tip of lower jaw to front edge of pectoral at its insertion $\ldots \ldots \ldots \ldots \ldots \ldots \ldots . . . .11 .0$

Tip of lower jaw to back edge of pectoral at its insertion $\ldots \ldots \ldots \ldots \ldots \ldots \ldots \ldots$

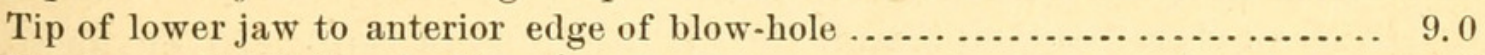

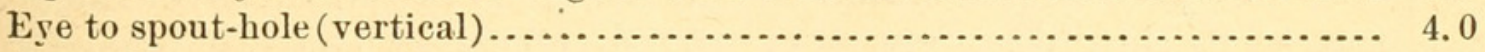

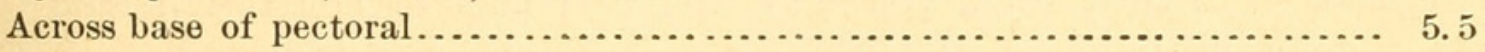

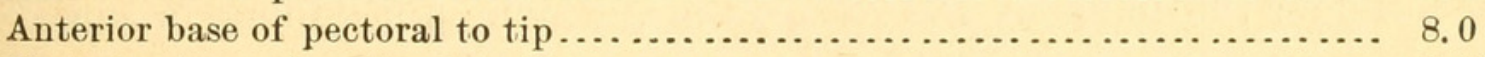

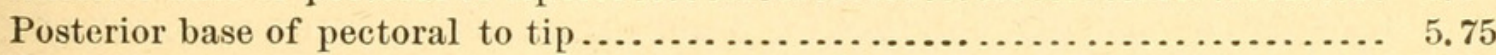

Tip of lower jaw to anterior boundary of the white area . . . . . . . . . . . 27.3

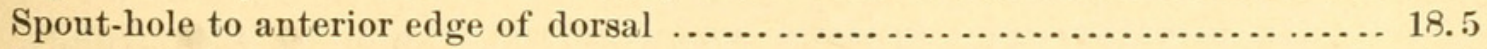

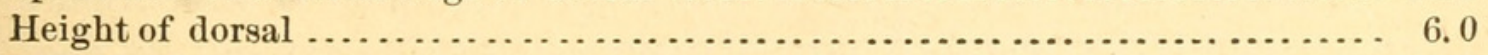

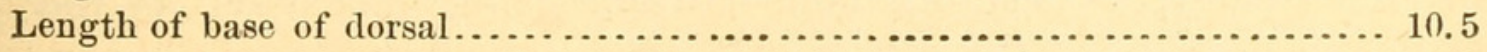

Proc. N. M. $85-7$ 


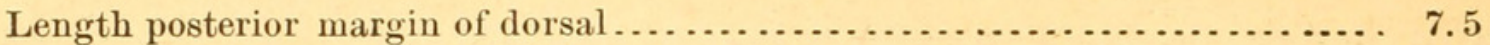

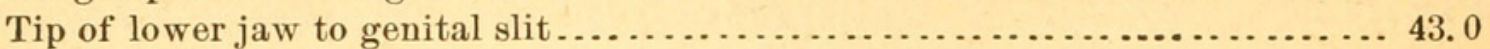

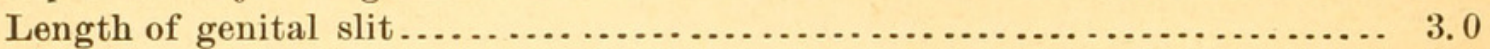

Genital slit to anus .............................................. 4.25

Anus to notch of the flukes......................................... 22.75

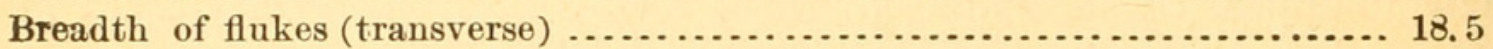

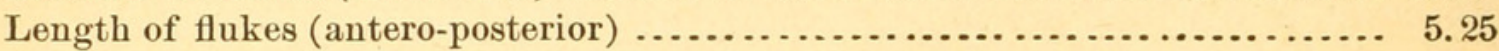

Breadth of narrowest part of tail before the flukes ..................... 1.75

Height of body at same point...................................... 3.5

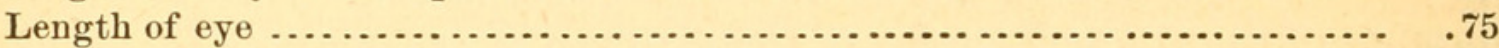

Width of spout-hole ................................................ 1.87

Extension of white area posterior to the anus......................... 6.5

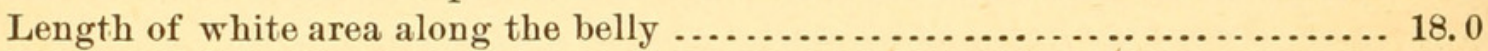

Width of head at corner of the mouth .............................. 5.5

Depth of body 24 inches anterior to the flukes (at which point the keels are widest) ......................................................... 10.0

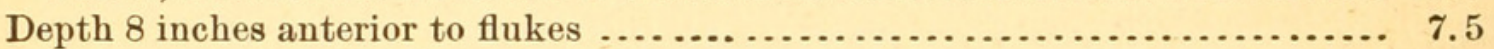

Navel to anterior end of genital slit...........................

Measurements of the type skull of Phocana Dalli, and of a skull of P. communis.

\begin{tabular}{|c|c|c|c|c|}
\hline \multirow{2}{*}{ Measurements. } & \multicolumn{2}{|c|}{$\begin{array}{l}P . \text { Dalli, Adakh } \\
\text { Id., Alaska. Type. }\end{array}$} & \multicolumn{2}{|c|}{$\begin{array}{l}\text { P. communis, East- } \\
\text { port, Me. } 9164 .\end{array}$} \\
\hline & Centim. & 100ths. & Centim. & 100ths. \\
\hline Total length.... & 33.3 & 100.0 & 26.0 & 100.0 \\
\hline Length of beak.. & 14. 0 & 42.0 & 11.7 & 44. 5 \\
\hline Breadth of beak at base of notches. & 9.5 & 28.5 & 7.8 & 29.5 \\
\hline Breadth of beak at its middle ...... & 5.7 & 17.1 & 4. 8 & 18. 5 \\
\hline Breadth of intermaxillaries at same point $\ldots \ldots \ldots \ldots \ldots \ldots$ & 3.5 & 10.5 & 2.2 & 8. 4 \\
\hline $\begin{array}{l}\text { Greatest breadth between outer margins of intermaxillaries } \\
\text { proximally } \ldots \ldots\end{array}$ & 5. 1 & 15.3 & 3.6 & 14.0 \\
\hline 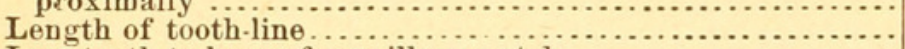 & 12.7 & 38.1 & 9.8 & $\begin{array}{l}14.0 \\
37.5\end{array}$ \\
\hline 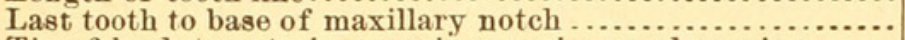 & 2.2 & 6. 7 & 2.3 & 8. \\
\hline Tip of beak to anterior margin superior nasal opening ...... & 17.8 & 53.4 & 14.8 & 56. \\
\hline 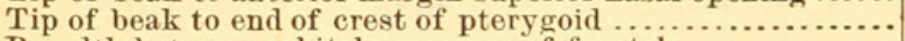 & 21. 3 & 64. 3 & $\cdots \cdots$ & \\
\hline Breadth between orbital processes of frontal............... & 16.5 & 49.5 & 12. 2 & 46. 8 \\
\hline Breadth between hinder margins of $t \in m$ poral fossæ ......... & 16. 2 & 48.6 & 12. 0 & 45. 7 \\
\hline 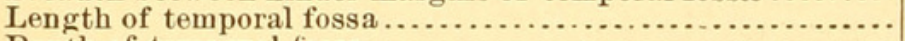 & 5. 6 & 16. 8 & 6. 3 & 24. \\
\hline 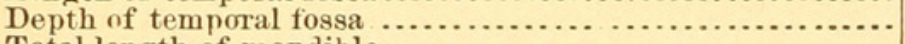 & 2. 6 & 7.8 & 4.2 & 16. 1 \\
\hline Total length of mandible... & 25.5 & 76.6 & .......... & $\cdots$ \\
\hline Length of symphysis of m & 3.8 & 11.4 & $\ldots \ldots \ldots$ & $\cdots \ldots \ldots$ \\
\hline Length of tooth-row of man & 12.2 & 36. 6 & $\ldots \ldots \ldots$ & . \\
\hline Depth between angle and corc & 5.7 & 17.1 & (............ & $\cdots$ \\
\hline Number of teeth ..... & $\left(\frac{23-23}{27-27}\right)$ & & $\left(\frac{27-28}{P-P}\right)$ & \\
\hline
\end{tabular}

ON PEUCAEA MEXICANA (LAWR.) A SPARROW NEW TO THE UNITED STATES.

\section{By ROAERT RIDGWAT.}

In Dr. J. C. Merrill's " Notes on the Ornithology of Southern Texas," \&c. (Proc. U. S. Nat. Mus., vol. i, p. 127), a species cf sparrow is mentioned under the name of Peuccea arizonce, which was "found in some abundance on a salt prairie about 9 miles from Fort Brown," and of which both specimen of the bird itself and its nest and eggs were obtained by Dr. Merrill. The species was referred by me to $P$. arizonce with some doubt, satisfactory identification being almost out of the question on account of the rather poor condition of the specimens examined, while the examples of $P$. arizona with which they were com. 


\section{$2 \mathrm{BHL}$ Biodiversity Heritage Library}

True, Frederick W. 1885. "On a new species of porpoise, Phocaena dalli, from Alaska." Proceedings of the United States National Museum 8(495), 95-98. https://doi.org/10.5479/si.00963801.8-495.95.

View This Item Online: https://www.biodiversitylibrary.org/item/52770

DOI: https://doi.org/10.5479/si.00963801.8-495.95

Permalink: https://www.biodiversitylibrary.org/partpdf/50970

\section{Holding Institution}

Smithsonian Libraries

\section{Sponsored by}

Smithsonian

\section{Copyright \& Reuse}

Copyright Status: Public domain. The BHL considers that this work is no longer under copyright protection.

This document was created from content at the Biodiversity Heritage Library, the world's largest open access digital library for biodiversity literature and archives. Visit BHL at https://www.biodiversitylibrary.org. 